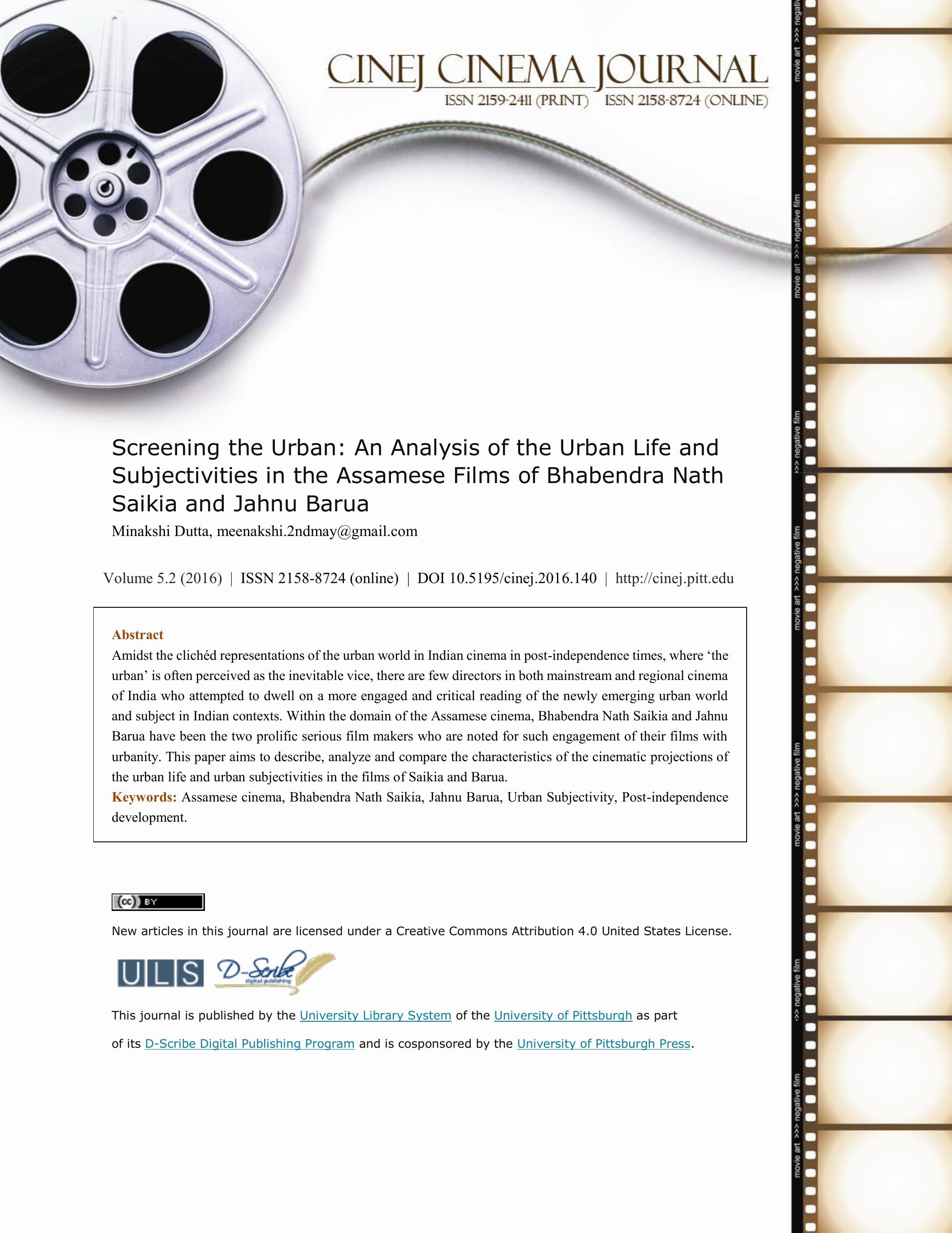




\section{Screening the Urban: An Analysis of the Urban Life and Subjectivities in the Assamese Films of Bhabendra Nath Saikia and Jahnu Barua}

\section{Minakshi Dutta}

Projection of the urban life world in films acquires significance, particularly in the context where the notion of urbanity is understood as the symbol of a 'newly encroaching world', popularly seen through the lenses of 'the rural' and 'the traditional'. Cinema had a complex and complicated relationship with urban life and subjectivity. From its inception, cinema is enthralled with the representation of the distinctive spaces, habits, lifestyles and human conditions of both urban and rural society. Scholars used to study cinema and city from two different standpoints; one is cinema in the city and another is city within the cinema. Both ways acquire significance in the field of cinema studies. Emergence of industrial society brings a modern way of life in the urban society. It is difficult to define urbanity or urban life with a particular definition.

'An often quoted example is Georg Simmel's famous essay on the metropolis and mental life. (Simmel, 1903). Money economy and intellectualism are closely connected phenomenon, he argues, and since large cities are the very centers of modern market economy, urban life is by necessity characterized by a high degree of rationalism expressed in a multitude of phenomena- for example, in how people organize their personal life, how they react to each other, which aesthetic preferences they develop, etc' (Larsen: 2007:29-30).

Partha Chatterjee mentions about 'inner' and 'outer' space, where village is identified as the inner space and which is free from 'outer' sphere of 'modern politics, economics, science and technology that was dominated by the west.' (Sarai: 2002:4) Nehru, who was an ardent follower of the 'development' of city expressed in his autobiography, Discovery of India, that 'the fundamental problem of India is not Delhi or Calcutta or Bombay but the villages of India.....we want to urbanize the village, not take away the people from the villages to town....because urbanization 
meant modernization, which was expected to lift India out of the morass of the past and set it on the road to progress' (Sarai: 2002:4). But despite the importance given to urbanity by Nehru, India has to wait to the end of the $20^{\text {th }}$ century for 'a large body of work on the sociological aspect of urban development'. (Bose: 2008: 38) Even in the field of cinematic representation also, till 1970 the space of the village was the 'central to imaginary', but when the 'unemployment rose rapidly and social movements with strong urban referents emerged throughout the country..... There was now a greater acknowledgement, even centrality of urban space.' (Mazumdar: 2007). According to Vasudevan,

The rise of the urban in 'our time' was given a certain urgency by globalization. Globalization, with its mixture of enforced commodification, spatial transformations and urban ruin, excavated the city from margins of academic and literary writing to a new public discourse that suddenly assumed the give-ness of urban space.

No doubt, like Nehru's view, urbanity brings progress and prosperity in society (Indian). But along with that the development of city or urbanity brings a 'spatial translation of the rupture between the modern and the traditional.' (Kaviraj: 2007: 60) Interestingly as an important form of visual arts, cinema became important in documenting and commenting on the process and impact of such changes. 'Thus the spectacle of the cinema both drew upon and contributed to the increased pace of modern city life, whilst also helping to normalize the frantic disadusted rhythms of the city.' (Clark: 3) So this kind of representation at one point helping the people to accept and entered in the new way of life. Like Clark, Peter Larsen also said that 'the cinematic sequence of shots presents a fragmented view of the world which matches the actual disorder of urban reality; on the other hand, the disorder may be solved by means of an interpretive montage producing insights 
into the historical situation and preparing the spectators for the inevitable, radical change.' (Larsen: 2007:31)

In an urban space, the subjectivity of each and every individual comes into a radical change. And in the films, directors construct their subjectivity in their own way of projection. 'Poststructuralism has emphasized that the subject is not a free consciousness or a stable human essence but rather a construction of language, politics and culture. Subjectivity can only be understood by examining the ways in which people and events are emplotted: inscribed in the narratives that cultures relentlessly weaves to fashion themselves.' (Cavallaro: 2001:86) The urban subjectivity is also constructed in literature, film and other art forms with some codes and conventions. Descartes, Schopenhaur, Nietzsche, Foucault, Lacan, and Walter Benjamin all these scholars give different views on human subjectivity. Foucault's approach focuses on 'the material dimension of history in order to show that subjects are not abstract entities but embodied beings' (Cavallaro: 2001: 90). And according to him 'a discourse could be described as a set of recurring statements that define a particular cultural object.'(Cavallaro: 2001: 90) He had negated all other reality except discourse. Lacan had made the language as the central to the construction of subjectivity. But Walter Benjamin describes subjectivity in a different way. In his famous article 'Toys and Play', he 'explores the idea of an erotic subjectivity that is a subject whose identity is in part constructed by the object world' (Latham: 50). In this essay 'toys relate us to the other by demanding to be used in specific ways' (Latham: 50). Applying this view in his cityscape he says that 'as the toys determine the play, the city imposes its alien rhythms upon the city dwellers. So, in these cityscapes, Benjamin simultaneously analyzes the city and the inhabitants of that city, based upon the interpenetration of city and subject' (Latham: 50) Therefore, it is the objects of urban world which build the urban subjectivity. Changing material forced human being to change

CINEJ Cinema Journal: Screenin the Urban: An Analysis of the Urban Life and Subjectivities in the Assamese Films...

Volume 5.2(2016) ｜ＩSSN 2158-8724 (online) ｜ DOI 10.5195/cinej.2016.140 | http://cinej.pitt.edu 
their habits, lifestyles and philosophy. So, the importance of objects in studying urban subjectivity is crucial.

Production and distribution of Indian cinema is closely associated with the expansion of urbanity. It has not only depicted the long process of urbanization 'as a struggle towards coming to terms with and formulating agendas for modernity, but also as reactions to and counter-programs against this process.' (Kaarsholm: 2007:1) With its composition, cinema 'offers aesthetic expressions of urban mass existence which are more adequate than most traditional art forms.' (Larsen: 2007: 31) In studying city in the cinema, where notion of urbanity is considered as 'newly encroaching world', urbanity is seen through the rural perspective.

The trend of making films on urban subjectivity is evident in Assamese cinema in post independent period. Films of that period were mostly based on the stereotypical model, where urban is projected as 'bad', 'emotionless', 'uncultured' etc. and village was the ideal place for living. Before 70s, Assamese cinema only favored to display the rural landscape of Assam. The city or urban space as a concept of cinematic representation was remained a crucial absence in the Assamese film history. It was director Bhabendra Nath Saikia, who endeavored to enter in the complex world of serious cinema by bringing the urban experience through camera. In representing urban subjectivity directors mainly follows two perspectives. Firstly, he read the society from inside i.e. from urban world and secondly; urban subjectivity is perceived from the rural world, where we witness the criticism of urbanity dominantly. Jahnu Barua, as follower of B.N Saikia also produced some films focusing on some urban issues. They had confronted with a range of urban themes: the transformation from traditional to modern; the emergence of the lonely hero; the crisis of joint family and loneliness of nuclear family; development of an insecure society 
for woman; etc. In this paper we are confining ourselves with some selected films of both Saikia and Barua, where urban subjectivity in the light of the above mentioned crisis is constructed.

Bhabendra Nath Saikia was a serious movie maker of Assam, who produced seven Assamese and two Hindi films from 70 s to 90 s focusing on some emerging issues of the society. One can easily notice that Saikia covered a particular group of people in his cinematic oeuvre. This group of people belongs to the urban world of Assam in particular and India in general. His seven Assamese films are a well documentation of the different stages of development of urbanity. If somewhere he pointed out the woman position in a urban middle class society (Sandhyaraag, 1977; Kolahal, 1988 and Agnisnsn, 1985)), in the other movies he had preferred to criticize the urbanity (Abartan,1993 and Itihaas,1996). Apart from these, in some movies, he had compelled us to think about the changing family relationship from individualistic approach (Sarathi, 1991) and lost dream of urban middle class couple also (Anirban, 1981). Directors are journeying through the traffic of codes and signs to construct a cinematic urban space in their films. Interestingly, the above mentioned themes are not in a water tight division. Some of the issues are dealt in almost all the films. For example, the issue of woman subjectivity in an urban environment is distinguished in almost all the films. Likewise, a critical look is always there for the urban lifestyle and ideology, which is also bring together with the other major issues.

In his article Realism and Fantasy in Representations of Metropolitan Life in Indian Cinema, M. Madhava Prasad mentioned that 'The spaces of the city are a site where struggles between opposing forces and desires, hopes and projections, are played out- confrontations between a governing will and a resistant population or between classes, rulers and ruled' (Prasad: 2007:83). Sandhyarag documented the crisis of these two groups of people- urban middle class and working class, who are living together with their own hopes and desires. Both of them are 
depending on one another but working class' fate is always decided by the urban middle class. In Prasad's term the urban middle class i.e Das' family is the 'ruler' and Saru, Taru, Moti (the driver) are the 'ruled'. Their lives are governed by the middle class family. This kind of relationship is common in an urban world; where subjectivity depends on his/her status or occupation.

In the same article Prasad quoted Henri Lefbvre's as 'urban life penetrates peasant life, disposing it of its traditional features: crafts, small centers which decline to the benefit of the urban centers.....villages become ruralized by losing their peasant specificity' (Prasad: 2007:83). The film Itihaas, starts with the story of a village nearby to the city, where people live with their culture and tradition, beliefs and customs. But one day for the sake of development, the villager had to leave that area. City planner planned to build multi-storied buildings on that particular land. Everybody with bag and baggage left their village and settled in another place. But fortunately or unfortunately, the village 'well', which is used as a metaphor to signify as the bearer of all changes, and the protagonist (Lakhimi) with her mother and sister, stayed there to witness the transformation of the society from rural to urban. It brokes their family into pieces. Her elder brother separates himself from the family and then the younger brother also left them in searching of a new job. In a nutshell, they had to scarify their happiness for the cost of development and at the end of the movie Lakhimi had committed suicide in that well. In his article The City and the Real: Chinnamul and the Left Cultural Movement in the 1940s, Moinak Biswas, said that 'The city as it appears on the screen is an entity in formation, a place that has just woken up to history itself. In a sense the village episode was still tucked away in some timeless place; these people have entered time now as an immediate experience. No escape from its course possible' (Biswas:2007:53) Transformation of village girl into a housemaid or part time maid in the urban world is an important 
feature covered by Saikia in his two films- Sandhyarag and Itihaas. His films are an exploration of the reason behind the creation of this section of the people in the society.

Ashish Nandy mentioned that 'the inner contradictions and tensions of the city-as-theself, which trigger the painful journey back to the village, are often the exact reverse of the inner contradictions and tensions of the village, which triggered the fateful journey to the city in the first place' (Nandy:2001:25). Poor economic condition of their family brings Saru and Taru to the urban society, where they encountered with another group of people. But staying there for a long period of time, they also colored with urbanity and when their employer sent them to their village, they become useless for rural environment. At the end of the movie, both of them once again journeyed to the city, with the help of an impotent taxi driver. Their journey from village to town; then town to village and then again village to town justifies Ashish Nandi's comment. At the same time it proves the theory of subjectivity of Benjamin, where he said that it is the object which construct the subjectivity of an individual. Staying in an urban world with modern technology and lifestyle a village girl turns into a member of urban world. While, in the film Itihaas, Lakhimi has to lose her life, after coming to a space 'inhabited by population, whose numbers can be counted more or less accurately, but whose mutual relationships cannot be easily specified' (Prasad: 2010:84). In this film Saikia had depicted such a society where 'individuals encounter each other as strangers, reified entities, whose position in a social network cannot be marked' (Prasad: 2010:84). In this regard Ackbar Abbas in his article "Cinema, the City and the Cinematic", he mentioned that "the city is erotic and becomes the site of our encounter with the other....the privileged site where the other is and where we ourselves are the other, and the site where one plays' (Krause:2003:45). The distance between two individuals of Itihaas is distinct in the treatment of the narrative. Living in 
a single apartment they hardly know each other, even the relationship of the son and daughter-inlaw of the old man is also poor.

Ranjani Mazumdar had rightly said that 'in imaginative terms, the 'village' is never absent from everyday life in the city. The narrative of migration and departure from home is a key part of urban life. The street in the city is a site for the flow of both rural and urban imagination' (Mazumdar: 2007: 4). Saikia's characters are somehow or somewhere related to a village. It may be Saru, Taru, Jayanti, Rajani or Lakhimi- all are village entities directly or indirectly. Rajani, the protagonist of Anirban is not a village man directly but his beliefs on some superstitious things establish him as a village man. This rural-urban relationship is common in Indian scenario. Urbanity is nothing but the developmental stage of rurality.

Whenever we see a paddy field and hut in the screen, immediately we recognize it as a village. Likewise, train line, busy road, smoking factory, passing truck, electric tower/post, multi storied building etc are the signifiers of an urban space. When Saru moving towards the city, director had quickened the tempo, 'where there is a sense of joyous enjoyment of the city's crowds and the rapid rhythms of its street life' (Kaviraj: 2007: 73) and the camera also captured the socalled signifier of an urban space. Travelling in a bus with her uncle, she was experiencing the city life with awful look through the window. In one shot Saikia had captured the standing buildings in his camera. After the introduction of the outer space of urbanity, Saru moves towards the inner space, where she firstly encountered an urban middle class family. With some POV shot, distinction between these two groups of people is shown in a distinct manner. Then, she is introduced with the kitchen space of an urban family again with some POV shots. It makes a difference between the kitchen of a village and a town. Here things are more disciplined and sophisticated. 
Agnisnan depicts an urban society of 40 s or 50 s, where a mixture of urbanity and rurality can be observed. Décor used by the director in this movie is time specific. Instead of showing bus, car, or electric tower he had used the street lamp, Ghora Bagi (a cart normally seen in Calcutta city and the director also brings it from there), police etc. Few English names and words are also given in Mohikanta's mouth to show the literacy and impact of English education. English education and classical music- these two are the symbols of modernity and Saikia had consciously incorporated these two features in his films. In Sandhyarag, the urban family is introduced with their interest in English education and music. In the morning scene of Sarathi also a girl with a tanpura is shown. Likewise, Itihaas depicted the morning of an urban society with morning walk and constant use of the term 'Good Morning'. Even in one scene, the old wise man asked Lakhimi to say 'Good Morning'. Thus she steps into the urban periphery.

In Anirban and Sarathi, Saikia moves from the outer world of urbanity into the inner anxiety of its inhabitants. School teacher Rajani and his wife in Anirban are constantly fighting with their fate and after losing their only daughter, Nisha, they are able to find a new hope in the face of Dibakar's wife. They lived in an urban area where school, hospital, rickshaw, bus etc are easily available. Kaviraj in his article Reading a Song of the City-Images of the City in Literature and Films, rightly said that ' the village constituted the space of tradition-of caste oppression, of stagnant customs, of poor and under developing lives, religious superstitions, The city, by contrast, was the space of the modern'(Kaviraj:2010:60). In Aniban both the above mentioned characteristics of village and town are apparent. Being a member of an urban society and being an educated man Rajani believed in superstition. Three examples are available in the film narrative. Sarathi signifies an individualistic approach towards urbanity, where an urban middle class man, from rural background, tries to analyze his position in his own family. Along with that he also 
dreams an ideal life with his beloved whom he cannot marry. Urbanity brings loneliness to a person at one stage of his life and at that moment each and every man, those who are from a village, recalled his village.

In the urban world, separation or division of space had an important role in day to day life. Cinema as a text is especially relevant to deal this dynamics of the space of urbanity. The importance of kitchen space is shown in the film Sarathi in a special manner, while the husband and wife were discussing about the construction of their dream house. Kitchen becomes an object to show their aristocratic position. And it is clearly mentioned that as only women are associated with kitchen she has the ultimate right to take the decision. Gardening becomes a fashion for the urban inhabitants. A separate space for gardening is always there in an urban house. These divisions of spaces create distance among the family members also.

Some characters like Benjamin's flaneur, who ' can recognize the real, as well as supposed character of the city's threats, intimidations, menaces or simply challenges to free access' (McNulty: 2005:54) are evident in Saikia's films also. Those characters are the real observer of the situation and like Benjamin's flaneur figure, 'a type of voyeur, he also chooses not to get involved directly with the city crowds. The crowd is the flaneur's element, yet the flaneur is not a man of the crowd.' (Ibid) In Sandhyarag, the character of Moti can be resembled with Benjamin's flaneur figure. In the whole narrative being an inhabitant of the urban world, he is out of the urbanity and he is the only person who exposed the deceitful nature of the urban people in front of Saru at the end of the movie. Though he and Saru, both were working in that house, unlike Saru, Moti always stayed outside the house. So being a part of urban society he is not within that. In the same way, Madhu and the old 'uncle' of the film Itihaas also played the same role in the narrative. Madhu is the boyfriend of Lakhimi and like flaneur; he refuses to become a part of the city. $\mathrm{He}$ 
knows about the 'good' and 'bad' of the modern society. He is the man, who at the beginning of the movie narrates the characteristics of the village using a voice-over. The old 'uncle' is also a member of that urban society but he is not like them. He had a soft corner for Lakhimi and her family. He tried to help them at his level. Though he belongs to that society, he also refuses to be a part of that society and in Benjamin's view, 'the heroism of this figure resides in the fact that he refuses to become part of the crowd.' (McNulty: 2005:54)

In Kolahal and Sarathi, another group of people with different characteristics emerged within the film narrative. This group of people is a distinctive part of urban landscape or in Ashish Nandi's word, 'the city that was never part of the formal 'master plan' but always implicit in it' (Prakash:2002:5). Living beside the city, these people always help the city dwellers in living their luxurious life smoothly. Ranjani Mazumdar identified this group of people as 'unintended city' and said that 'the bulk of the people in the 'unintended city' are poor migrants who flock to cities in search of work and a better life'. While planners build the city for cars and the urban elite, causing many hardships for those belonging to the 'unintended city', the juxtaposition of a 'master plan' and its unintended consequences gives rise to a space where both the rural and the urban coexist, sometimes in conflict with each other and sometimes in harmony'(Mazumdar:2007:5). In Sarathi, in one part of the movie director had captured a small story of a young couple of the workers working in the construction site. The protagonist also noticed their relationship and flash back to past and imagined his desired life. The story of Kolahal centered on the day to day life of a society near to a city. Each and every characters are living without any dream. They are living by helping the urban dwellers. The inner environment of such place is beautifully depicted by the director with some shots. Alcohol consumption is regular habit of the male members of the place. In such situation the life and security of woman and children are also in danger. Children are 
engaged in some dangerous work and women are targeted for sexual harassment by both the city and 'unintended city' dwellers. Saikia had dwell upon the above mentioned issues in Kolahal, which is a unique step in Assamese film history.

After Saikia, internationally acclaimed prolific filmmaker, Jahnu Barua also contributed some movies on some complex issues of urban society and subjectivity. In the year 1995, he produced a movie called Xagaraloi Bahu Dur-It's a Long Way to the Sea (XBD), which is able to receive various national and international awards. It's a critical introspection of the urban society. Here urbanity is explored by an old village man, Powal and his grandson, Suman. Getting the invitation from his town living son, Basanta, both of them went to Guwahati town for a visit. Unfortunately, in this visit they had discovered some facts about urban people through his elder son and his wife. Barua always applied a pessimistic lens in dealing the city dwellers. In this film also, from the beginning he had shown the son and his wife as selfish couple. In introductory scene, Basnata talked about faking signature of his father for selling his land. The film opens with the description of a typical village but in between the narrative Powal and Suman journeyed to the city and explored it. Director Barua had constructed the cityscape with the Chandmari over bridge, cars, bikes etc. The internal settings of Basanta's house and his ambassador car demarcate him as an urban inhabitant. His children are also fond of English music and Cricket. His wife, with costly ornaments and Sare, placed her as a member of that society. With all these arrangements Barua is successful in creating an impression about the urban subjectivity. Likewise, the conversation between Basanta and his wife about their father and the land shows their narrow and selfish mentality.

In his another movie Konikar Ramdhenu (2002), Barua had uncovered some hidden issues of urban society. A court is a product of modernity and it is an essential institution of an 
urban area. Starting with a shot of a judicial court, Barua entered in the world of urbanity. A nine years old boy Kukoi of a remote village of Sivsagar district is arrested for killing his employer at Guwahati. He is sent to the juvenile home and there he met one old man called Biswa Boro, who at the end of the movie took him to his village. The story behind the murder is explained with many flashbacks. Soon after his arrival at the juvenile home, audience can explore some inhuman activities of the urban 'bhadralok'. The child molestation is the major issue covered in the film. Along with these, other unlawful activities are also a part of the narrative. Like the protagonists of Saikia's films, here also struggling with the poor economic condition, Kukoi moves to Guwahati city for survival. But in the urban environment he had to encounter with some problems and ultimately he had to go back to the village again. In this sense, Ashish Nandis's view on the journey from city to village and village to city will be a relevant one. At the end of the movie director had hinted about the dark future of the urban society. According to him to be a good man Kukoi's journey to a village is essential. Same philosophy is applied in $X B D$ also.

Guwahati is always explored and defined in various forms of art and literature. Comparing to other art forms, cinema represents Guwahati slightly later. In the above mentioned movies of Barua, Guwahati city is represented in a distinct manner. He had depicted Guwahati as a city of homelessness and as a city of insecurity, where old village man like Powal and small boy like Kukoi had to suffer a lot. As Ashish Nandy has pointed out,

"the Indian city has re-emerged in public consciousness not as a new home, from within the boundaries of which one has the privilege of surveying the ruins of one's other abandoned homes. It has re-emerged as the location of a homelessness forever trying to reconcile non-communitarian individualism and associated forms of freedom with communitarian, freely or involuntarily borne responsibilities. Apparently, the city of the mind does not fear homelessness; it even celebrates homelessness" (Nandy: 2001:25). 
In $X B D$, though Hemanta is away from his father, he and his wife, daughter and son never feels that. In fact they are happy to stay away from him. Barua's vision of the city is thus a partial construction designed to emphasize the fragmented social relationships of city dwellers and poverty of their attempts at communication and interaction.

\section{Conclusion}

Thematically, both Saikia and Barua produced films on urban lifestyle and subjectivity. However, while we observe their treatment and approach, they differ from one another. In his films, Barua always deny urbanity, whereas Saikia tried to give a solution by staying within that urbanity. $X B D$ and Konikar Ramdhenu are the examples of such negation. His characters always prefer to go back to village. Say for example, Powal of $X B D$ back to his village Nemuguri and Biswa Boro of Konikar Ramdhenu also preferred to bring the boy Kukoi to his village. Barua's character moves to town by facing some problem in the village, but ultimately they had to return to the same place. But Saikia's characters tried to cope up with the situation and became a part of urbanity. Saru and Taru of Sandhyarag decided to settle in town with Moti; Jayanti of Abartan also started a new life with Porimal in town; in Sarathi, the frustrated middle class man is ready to live his life in the same situation with his memories; Kiran of Kolahal accepts Badal for leading her future life, the unfortunate couple of Anirban also find a new hope in the face of Dibakar and his wife. Barua had taken the rural perspective in dealing the urban issues and he had not left any space for the audience and also for the characters to think about good side of 'development', 'progress' or urbanity. He had followed the stereotypical model of urban representation, but Saikia had created a space for the positive side of urbanity. In comparison to Barua, Saikia had given a clear vision of the urban lifestyle and subjectivity. Barua's intension is 
to read urban subjectivity through rural lens, whereas Saikia tried to explore it by staying within the periphery of urbanity. Maybe for that reason in the construction of cityscape Saikia is more conscious and matured than Barua. But with their cinematic oeuvre both the directors had documented the process of urbanization stage by stage.

\section{BIBLIOGRAPHY}

Biswas, Moinak "The City and the Real: Chhinnamul and the Left Cultural Movement in the 1940s." In City Flicks: Indian Cinema and Urban Experience, by Preben Kaarsholm, 40-59. Calcutta: Seagull Books, 2010.

Bose, Brinda. "Modernity, Globality, Sexuality and the City: A Reading of Indian Cinema." The Global South, 2008: 35-58.

Cavallaro, Dani. Critical and Cultural Theory: Thematic Variations. London: Athlone Press, 2001.

Kaarsholm, Preben . "Introduction: Unreal City: Cinematic Representation, Globalization and the Ambiguities of Metropolitan Life." In City Flicks: Indian Cinema and Urban Experience, by Preben Kaarsholm, 1-25. Calcutta: Seagull Books, 2010.

Kaviraj, Sudipta. "Reading a Song of the City: Images of the City in Literature and Film." In City Flicks: Indian Cinema and Urban Experience, by Preben Kaarsholm, 60-81.

Calcutta: Seagull Books, 2010.

Krause, Linda, and Patrice Petro. Global Cities: Cinema, Architecture, and Urbanism in a Digital Age. London: Rutgers, 2003.

Larsen, Peter. "Urban Legends: Notes on a Theme in Early Film Theory." In City Flicks:

Indian Cinema and Urban Experience, by Preben Kaarsholm, 26-39. Calcutta: Seagull Books, 2010 .

Lathan, Jacob Adhram. "The City and Subject: Benjamin on Language, Materiality and Subjectivity."http://www.epoche.ucsb.edu/Latham06.pdf. (Accessed November 20, 2013). 
Mazumdar, Ranjani. Bombay Cinema: An Archieve of the City. India: Oxford, 2007.

Nandy, Ashish. An Ambiguous Journey to the City- The Village and Other Odd Ruins of the Self in the Indian Imagination. New York: Oxford UP, 2001.

McNulty, Niall (2005) Reading the City: Analyzing the Literary Space in Selected Postapartheid Urban Narratives, University of KwaZulu-Natal

http://researchspace.ukzn.ac.za/xmlui/handle/10413/3800

Prakash, Gyan. "The Urban Turn." Sarai- The Cities of Everyday Life, 2002.

Prasad, Madhava. M. "Realism and Fantasy in Representations of Metropolitan Life in Indian Cinema." In City Flicks: Indian Cinema and Urban Experience, by Preben Kaarsholm, 82-98. Calcutta: Seagull Books, 2010. 